\title{
Epidermoid cysts localized on extremities
}

\author{
Ekstremite yerleşimli epidermoid kistler
}

\author{
Ozan Beytemür, MD, Serdar Yüksel, MD
}

Department of Orthopedics and Traumatology, Bağcılar Training and Research Hospital, İstanbul, Turkey

\begin{abstract}
Objectives: This study aims to investigate the incidence, anatomic localization, relationship to trauma, treatment complications, relapse ratios after treatment, and factors affecting relapse of epidermoid cysts localized on the extremities.

Patients and methods: The study evaluated retrospectively 120 patients (76 males, 44 females; mean age 41.8 years; range 9 to 76 years) diagnosed with and operated due to epidermoid cyst localized on the extremities between January 2012 and June 2017. Patients' age, gender, cyst's localization, anatomic localization, complaint duration, and trauma history were investigated as well as whether a cutaneous islet was left on the cyst and whether any cyst rupture occurred intraoperatively; and relapse and association of relapse ratios with these parameters.
\end{abstract}

Results: There was no statistically significant difference between patients with or without relapse in terms of age, gender distribution, or cyst size or localization ( $\mathrm{p}>0.05$ ). Relapse ratios were significantly lower in patients in whom a cutaneous islet was left intraoperatively $(\mathrm{p}<0.05)$. Relapse ratios were significantly higher in patients who developed intraoperative cyst rupture $(\mathrm{p}<0.05)$. There was no significant relationship between relapse and trauma history $(\mathrm{p}>0.05)$. Intraoperative cyst rupture ratios were significantly lower in patients in whom a cutaneous islet was left intraoperatively $(\mathrm{p}<0.05)$.

Conclusion: Epidermoid cysts are most frequently localized on the hands. They may also be atypically localized with different dimensions and characteristics. Well definition of the cyst margins and characteristics and avoiding intraoperative rupture while excising the cyst together with the cutaneous islet are essential to reduce possible postoperative complications and relapse ratios.

Keywords: Epidermoid cyst; extremity; relapse.

Epidermoid cysts are also called inclusion cysts, epidermal inclusion cysts, epithelial cysts, keratin cysts, implantation cysts or traumatic or post-traumatic epidermoid inclusion cysts. All these cysts include an epidermal layer with keratin. Epidermoid cysts are benign lesions which include a cystic space with keratin and formations of three
Öz

Amaç: $\mathrm{Bu}$ çalışmada ekstremite yerleşimli epidermoid kistlerin insidansı, anatomik yerleşimi, travmayla ilişkisi, tedavi komplikasyonları, tedavi sonrası nüks oranları ve nüksü etkileyen faktörler araştırıldı.

Hastalar ve yöntemler: Çalışmada Ocak 2012 - Haziran 2017 tarihleri arasında ekstremite yerleşimli epidermoid kist tanısı konmuş ve bu nedenle ameliyat geçirmiş 120 hasta (76 erkek, 44 kadın; ort. yaş 41.8 yıl; dağılım 9-76 yıl) retrospektif olarak değerlendirildi. Hastaların yaşı, cinsiyeti, kistin yerleşim yeri, anatomik yerleşimi, yakınma süresi ve travma öyküsü ile beraber ameliyat sırasında kist üzerinde kütanöz adacık bırakılıp bırakılmadığı ve kist rüptürü olup olmadığı, nüks oranları ve nüks oranlarının bu parametrelerle ilişkisi araştırıldı.

Bulgular: Nüks olan ve olmayan hastalarda; yaş, cinsiyet dağılımı, kistin büyüklüğü ve yerleşim yeri açısından istatistiksel olarak anlamlı farklılık yoktu $(\mathrm{p}>0.05)$. Ameliyat sırası kütanöz adacık bırakılan hastalarda nüks oranları anlamlı olarak daha düşüktü $(\mathrm{p}<0.05)$. Ameliyat sırası kist rüptürü meydana gelen hastalarda nüks oranları anlamlı olarak daha yüksekti $(\mathrm{p}<0.05)$. Nüks ve travma öyküsü arasında anlamlı ilişki yoktu $(\mathrm{p}>0.05)$. Ameliyat sırası kist rüptürü oranları kütanöz adacık bırakılan hastalarda anlamlı olarak daha düşüktü $(\mathrm{p}<0.05)$.

Sonuç: Epidermoid kistler en sık elde yerleşimlidir. Farklı boyut ve karakterlerde, atipik yerleşimli de olabilir. Ameliyat sonrası olası komplikasyonları ve nüks oranlarını azaltmak için kistin sınırlarını ve özelliklerini iyi tanımlamak ve kisti kütanöz adacıkla beraber eksize ederken ameliyat sırası rüptürden kaçınmak gerekir.

Anahtar sözcükler: Epidermoid kist; ekstremite; nüks.

germinal layers and connected with the upper skin. ${ }^{[1]}$ They are detected in the soft tissue in general and located subcutaneously (Figure 1); however, they may present intratendinous, subungual or intraosseous localizations. ${ }^{[2]}$ These cysts appear through invagination of keratinized squamous epithelium into deeper tissues because of trauma or

- Received: October 02, 2017 Accepted: December 11, 2017

- Correspondence: Ozan Beytemür, MD. Bağcılar Eğitim ve Araştırma Hastanesi Ortopedi ve Travmatoloji Anabilim Dalı, 34200 Bağcılar, İstanbul, Turkey. Tel: +90 530 - 8200992 e-mail: beytemur@yahoo.com 
surgery. Although they are detected on whole body areas which are covered by squamous epithelium, they are commonly observed on head and neck and face, torso, scalp, and rarely on extremities. ${ }^{[3]}$ They grow very slowly as a result of desquamation of normal cells into cystic cavity; therefore, they present an asymptomatic pattern. The cysts become symptomatic when malign transformation occurs; they rupture, enlarge, and become infected. Some patients complain about mechanical problems due to the effect of the mass whereas some have cosmetic complaints due to its appearance. The most important complication is malign transformation and the probability of conversion from an epidermoid cyst to squamous cancer, which was reported to be between $0.11 \%$ and $0.045 \% .{ }^{[4]}$

Comprehensive research in the literature related to certain characteristics of epidermoid cysts is limited. Therefore, in this study, we aimed to investigate the incidence, anatomic localization, relationship to trauma, treatment complications, relapse ratios after treatment, and factors affecting relapse of epidermoid cysts localized on the extremities.

\section{PATIENTS AND METHODS}

In this study, we evaluated retrospectively 120 patients (76 males, 44 females; mean age 41.8 years; range 9 to 76 years) diagnosed with and operated due to epidermoid cyst localized on the extremities at Bağcllar Training and Research Hospital between January 2012 and June 2017. Radiological evaluations through direct X-ray and magnetic resonance imaging (MRI) were performed on all patients. MRI generally revealed a superficial, subcutaneous cystic lesion which was hyperintense in $T_{2}$ scans and hypointense in $T_{1}$ scans with regular margins and without edema (Figure 2). After investigation of the patient history, clinical evaluation and radiological examination, such lesions were considered as benign; therefore, direct marginal excision was planned by considering surgical principles of tumor excision without any biopsy before the surgery. The indication for surgical excision of these tumors was being symptomatic such as pain, swelling, and limitation of range of motion. Patients' age, gender, cyst's localization, anatomic localization, complaint duration, and trauma history were investigated as well as whether a cutaneous islet was left on the cyst and whether any cyst rupture occurred intraoperatively; and relapse ratios and association of relapse ratios with these parameters. A written informed consent was obtained from each patient. The study was conducted in accordance with the principles of the Declaration of Helsinki.

All patients were taken into operation through pneumatic tourniquet application by elevation of the concerning extremity without Esmarch bandage (VBM Medizintechnik $\mathrm{GmbH}$, Sulz a N, Germany) if anatomic localization allowed under regional anesthesia. The mass was marginally excised by preferring skin incision depending on anatomic characteristics of the region. In some cases, a cutaneos islet was excised with the lesion (Figure 3). The surgical site was closed after bleeding control and irrigation without leaving any dead-space. In the cases with a ruptured cyst; a viscous, white-colored cyst content, which is typical in epidermoid cysts, was observed.

All cases had a routine histopathological examination and were diagnosed with epidermoid cyst. A cystic formation derived from squamous epithelium including keratin debris was observed in histopathological examination (Figure 4).

All surgical procedures were performed by two surgeons experienced in musculoskeletal system
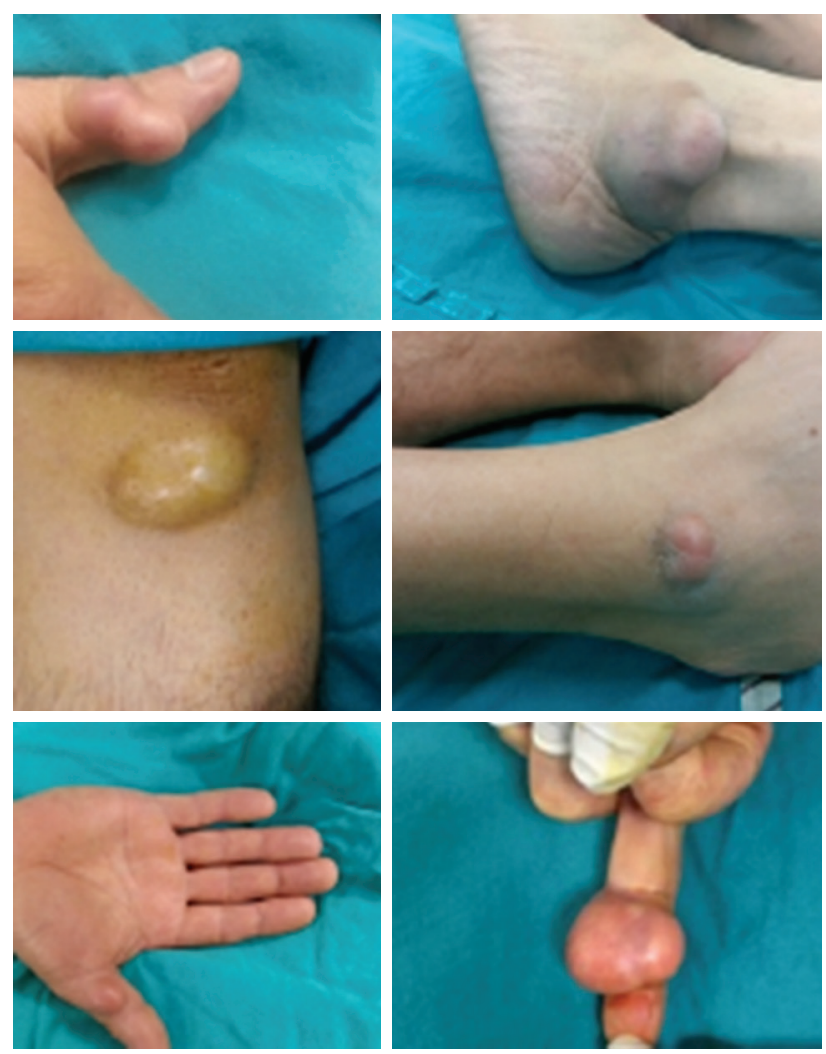

Figure 1. Macroscopic appearance of lesions at different localizations. 


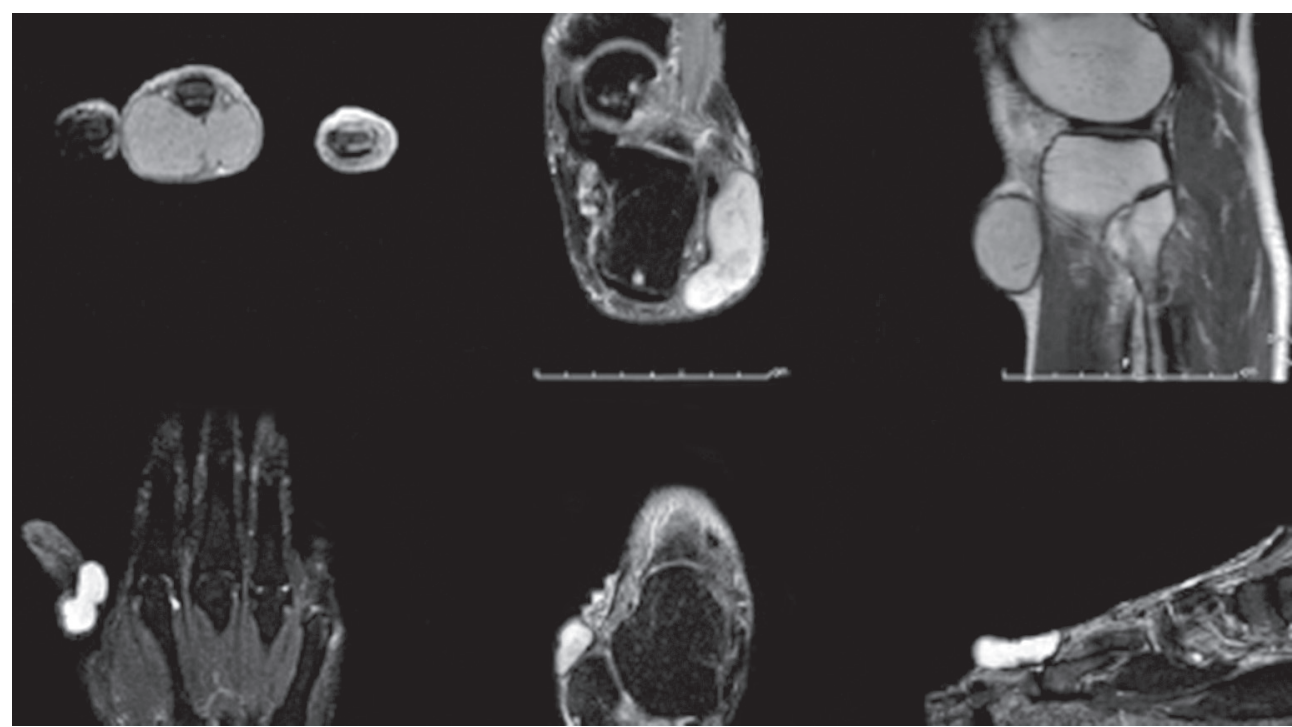

Figure 2. Preoperative magnetic resonance examination at different localizations.

tumors. Moreover, all samples were evaluated by a single pathologist experienced in musculoskeletal system. The patients were invited for routine control visits after discharge. After removal of the sutures, controls were conducted monthly during the first three months, quarterly within the first year, and then annually.

\section{Statistical analysis}

IBM SPSS Statistics version 22.0 (IBM Corp., Armonk, NY, USA) was used for statistical analyses.
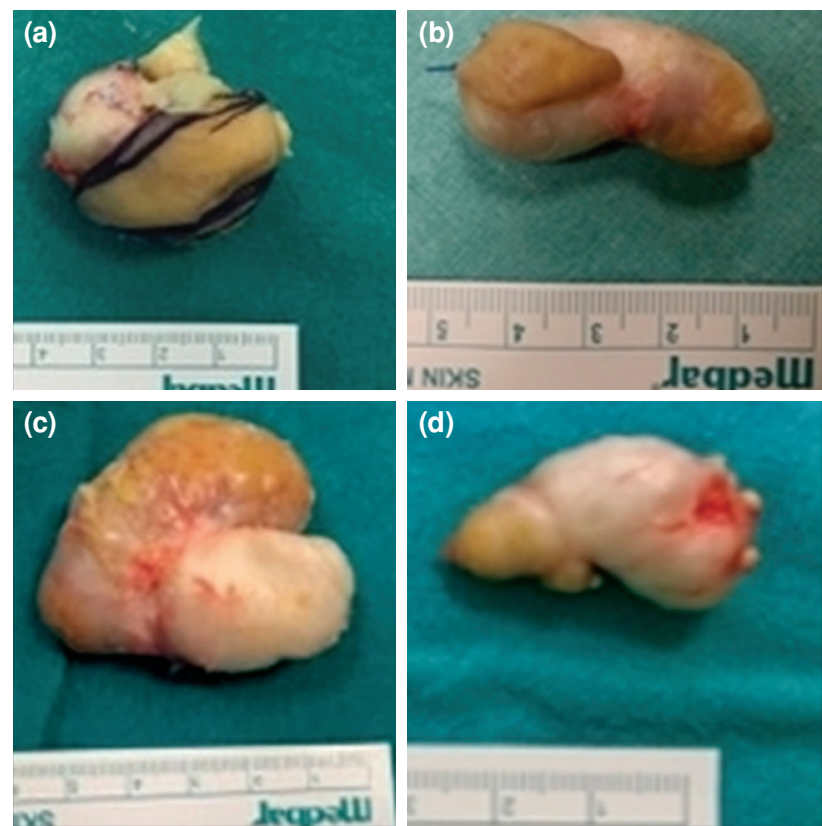

Figure 3. Macroscopic appearance of lesions after surgical excision, (a, b) Without skin islet, (c, d) with skin islet.
Means, standard deviations, medians, minimums, maximums, frequencies, and ratios of the data were used for descriptive statistical analysis. Distribution of the variables was measured by Kolmogorov-Smirnov test. Mann-Whitney $U$ test was used for analysis of independent quantitative data. Chi-square test was utilized to analyze independent qualitative data.

\section{RESULTS}

Mean size of the masses was $2.2 \mathrm{~cm}$ (range $0.5-9 \mathrm{~cm}$ ) (Table I). However, $6.6 \%(n=8)$ of such masses were over $5 \mathrm{~cm}$ and they were considered as large epidermoid cysts. The masses were localized on

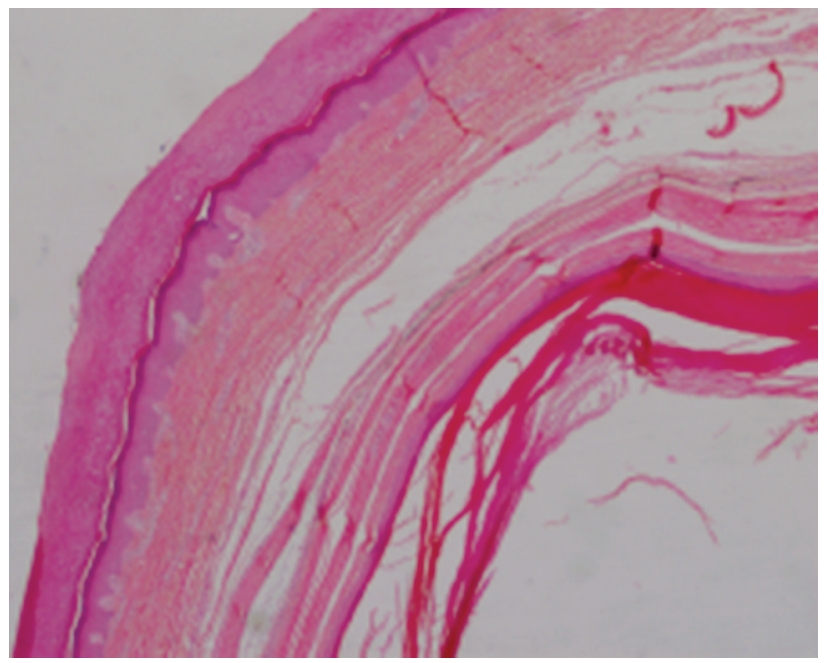

Figure 4. Histopathological appearance of lesion: There is ortokeratotic hyperkeratosis on epidermis of finger surface. Cyst was lined by squamous epithelium in dermis and contained lamellated keratin $(\mathrm{H}-\mathrm{E} \times 40)$. 
TABLO I

Demographic and surgical characteristics of patients

\begin{tabular}{|c|c|c|c|c|c|}
\hline & $\mathrm{n}$ & $\%$ & Mean $\pm S D$ & Median & Min-Max \\
\hline Age (year) & 44 & 36.7 & $41.8 \pm 14.8$ & 40.5 & $9.0-76.0$ \\
\hline \multicolumn{6}{|l|}{ Gender } \\
\hline Female & 44 & 36.7 & & & \\
\hline Male & 76 & 63.3 & & & \\
\hline Size $(\mathrm{cm})$ & & & $2.2 \pm 1.4$ & 2.0 & $0.5-9.0$ \\
\hline \multicolumn{6}{|l|}{ Side } \\
\hline Right & 64 & 53.3 & & & \\
\hline Left & 56 & 46.7 & & & \\
\hline \multicolumn{6}{|l|}{ Residential } \\
\hline Lower & 36 & 30.0 & & & \\
\hline Upper & 84 & 70.0 & & & \\
\hline Duration of complaint (month) & & & $19.9 \pm 19.8$ & 12.0 & $3.0-120.0$ \\
\hline Follow-up (month) & & & $22.4 \pm 9.3$ & 21.0 & $3.0-48.0$ \\
\hline \multicolumn{6}{|l|}{ Skin islet } \\
\hline- & 56 & 46.7 & & & \\
\hline+ & 64 & 53.3 & & & \\
\hline \multicolumn{6}{|l|}{ Intraperative rupture } \\
\hline- & 84 & 70.0 & & & \\
\hline+ & 36 & 30.0 & & & \\
\hline \multicolumn{6}{|l|}{ Trauma } \\
\hline- & 64 & 53.3 & & & \\
\hline+ & 56 & 46.7 & & & \\
\hline \multicolumn{6}{|l|}{ Relapse } \\
\hline- & 108 & 90.0 & & & \\
\hline+ & 12 & 10.0 & & & \\
\hline
\end{tabular}

SD: Standard deviation; Min: Minimum; Max: Maximum.

the right side in $53.3 \%$ and on the left side in $46.7 \%$ of the cases. Localizations of the masses were upper extremity in $70 \%$ and lower extremity in $30 \%$ of the patients. Fifty percent $(50 \%)$ of the cases with localization on upper extremity were on the forearm. Mean complaint period was 19.8 months and follow-up period was 22.4 months. Intraoperative rupture developed in $30 \%$ of the patients. The cyst was excised with the cutaneous islet in $53.3 \%$ of the patients. Trauma history was detected in $56 \%$ of the patients. Twelve patients $(10 \%)$ had postoperative relapse. No postoperative incision site complication or infection was observed in any patient.

There was no statistically significant difference between patients with or without relapse in terms of age, gender distribution, or cyst size or localization ( $p>0.05)$. Relapse ratios were significantly lower in patients in whom a cutaneous islet was left intraoperatively $(p<0.05)$. Relapse ratios were significantly higher in patients who developed intraoperative cyst rupture $(\mathrm{p}<0.05)$. There was no significant relationship between relapse and trauma history ( $p>0.05)$ (Table II). Intraoperative cyst rupture ratios were significantly lower in patients in whom a cutaneous islet was left intraoperatively $(\mathrm{p}<0.05)$ (Table III).

\section{DISCUSSION}

While case reports of epidermoid cysts exist in the literature, comprehensive research on this subject is not sufficient. Studies have been performed on a limited number of anatomic regions such as hand or foot only. Except the case series of Dutta et al. ${ }^{[5]}$ including 28 cases with head and neck cysts and Lincoski et al. ${ }^{[6]}$ including 101 cases with hand cysts, others were case reports. As far as we know, there is no study on epidermoid cysts localized on the extremities. Therefore, we believe that the present study is the first and most comprehensive providing detailed information about epidermoid cysts localized on the extremities.

There are different theories about the etiology of epidermoid cysts. McFarland ${ }^{[7]}$ suggested that a 
TABLE II

Demographic and surgical characteristics in patients with and without relapse

\begin{tabular}{|c|c|c|c|c|c|c|c|c|c|}
\hline & \multicolumn{4}{|c|}{ Relapse (-) } & \multicolumn{4}{|c|}{ Relapse (+) } & \multirow[b]{2}{*}{$p$} \\
\hline & $\mathrm{n}$ & $\%$ & Mean $\pm S D$ & Median & $\mathrm{n}$ & $\%$ & Mean $\pm S D$ & Median & \\
\hline Age (year) & & & $41.3 \pm 15.1$ & 40.5 & & & $46.6 \pm 10.4$ & 42.0 & $0.229^{*}$ \\
\hline \multicolumn{10}{|l|}{ Gender } \\
\hline Female & 40 & 37.0 & & & 4 & 33.3 & & & $0.801 \ddagger$ \\
\hline Male & 68 & 63.0 & & & 8 & 66.7 & & & \\
\hline Size $(\mathrm{cm})$ & & & $2.0 \pm 1.0$ & 2.0 & & & $3.8 \pm 2.8$ & 3.0 & $0.027^{*}$ \\
\hline Side & & & & & & & & & $0.143 \ddagger$ \\
\hline Right & 60 & 55.6 & & & 4 & 33.3 & & & \\
\hline Left & 48 & 44.4 & & & 8 & 66.7 & & & \\
\hline Residential & & & & & & & & & $0.791 \ddagger$ \\
\hline Lower extremity & 32 & 29.6 & & & 4 & 33.3 & & & \\
\hline Upper extremity & 76 & 70.4 & & & 8 & 66.7 & & & \\
\hline Duration of complaint (month) & & & $18.7 \pm 19.0$ & 12.0 & & & $31.3 \pm 24.2$ & 17.0 & $0.028^{*}$ \\
\hline Follow-up (month) & & & $23.1 \pm 9.5$ & 21.5 & & & $16.3 \pm 4.7$ & 17.0 & $0.006^{*}$ \\
\hline Skin islet & & & & & & & & & $0.001 \ddagger$ \\
\hline- & 45 & 41.7 & & & 11 & 91.7 & & & \\
\hline+ & 63 & 58.3 & & & 1 & 8.3 & & & \\
\hline Intraperative rupture & & & & & & & & & $0.003 \neq$ \\
\hline- & 80 & 74.1 & & & 4 & 33.3 & & & \\
\hline+ & 28 & 25.9 & & & 8 & 66.7 & & & \\
\hline Trauma & & & & & & & & & $0.393 \ddagger$ \\
\hline- & 59 & 54.6 & & & 5 & 41.7 & & & \\
\hline+ & 49 & 45.4 & & & 7 & 58.3 & & & \\
\hline
\end{tabular}

SD: Standard deviation; * Mann-whitney u test; $\ddagger$ Chi-square test.

traumatic event inclines keratinized epithelium into the subcutaneous tissue and epidermoid cysts appear when squamous epithelium grows and produces keratin. Wien and Caro $^{[8]}$ showed in their experimental study that implantation of epidermal tissue into the dermis causes dermoid cyst formation. Carroll ${ }^{[9]}$ advocated the theory that epidermoid cyst appears by proliferation and growth of epidermal cells at rest inside the dermis after being activated through a blunt and minor trauma. In the present study, we could detect trauma history in only $46.7 \% \quad(n=56)$ of patients with epidermoid cyst in soft tissue on the extremities. Therefore, we believe that trauma and history of previous surgery constitute predisposing factors for formation of epidermoid cyst; however, other causes should exist as well.

Epidermoid cysts generally appear on the scalp, and head and neck. These cysts are rare on the extremities. Those localized on the extremities are more common on upper extremities than lower extremities. ${ }^{[10]}$ Epidermoid cysts of the hand are commonly observed on volar side of the hand and fingers and it is believed that cysts localized on the hand appear as a result of

TABLE III

Incidence of intraoperative rupture in patients who were left or not left with a skin islet on lesion during surgery

\begin{tabular}{|c|c|c|c|c|c|}
\hline & \multicolumn{2}{|c|}{ Skin islet (-) } & \multicolumn{2}{|c|}{ Skin islet $(+)$} & \multirow[b]{2}{*}{$p^{*}$} \\
\hline & $\mathrm{n}$ & $\%$ & $\mathrm{n}$ & $\%$ & \\
\hline Intraperative rupture & & & & & 0.000 \\
\hline- & 26 & 46.4 & 58 & 90.6 & \\
\hline+ & 30 & 53.6 & 6 & 9.4 & \\
\hline
\end{tabular}

* Chi-square test. 
implantation of epidermal elements into dermis after a trauma. ${ }^{[6,11]}$ Lincoski et al.$^{[6]}$ found the incidence ratio of epidermoid cyst as $16 \%$ in their study where 623 masses were localized on the hand and forearm. Since we only evaluated cases that were diagnosed as epidermoid cyst histopathologically, we cannot provide such a ratio; however, we detected that $50 \%(n=60)$ of the cases were localized on the hand and forearm.

Magnetic resonance imaging is the most common imaging method for diagnosis. Patients with typical localization such as the volar side of the hand and previous penetrating trauma or history of surgery are quite easy to diagnose. However, diagnosis is difficult for those with atypical localizations, infected or ruptured cysts. In such cases, preoperative MRI is suggested. However, we use MRI routinely to reveal anatomic characteristics, invasion of a lesion, and for surgical procedure planning etc. Like all soft tissue tumors, MRI helps to detect margins, content, anatomic characteristics, and benign-malign differentiation of a lesion. ${ }^{[12]}$ Such cysts are observed as homogeneous, $\mathrm{T}_{1}$ hypointense, and $\mathrm{T}_{2}$ hyperintense lesions with regular margin. ${ }^{[13]}$ Some authors recommend ultrasonography (USS) for preoperative evaluation; ${ }^{[14]}$ however, we do not prefer USS since it depends on the performer and does not provide much information except cysticsolid differentiation. Dutta et al. ${ }^{[5]}$ recommended preoperative free needle aspiration cytology (FNAC) and computed tomography (CT) in the cases with atypical presentation, if necessary, in a study published for epidermoid cysts of head and neck. The procedures mentioned above are not cost-effective and we believe that FNAC wastes the time of patients and surgeons, while CT causes unnecessary exposure to radiation and may not provide detailed information on soft tissue when compared to MRI. An accurate patient history, physical examination, direct X-ray, and MRI may provide a correct diagnosis. Since the lesion has a cystic formation with a viscous content, biopsy may cause rupture and then relapse. In the present series including 120 cases, all of the patients who were considered as benign cyst were histopathologically reported as epidermoid cyst. Although tendon sheath giant cell tumors are considered for differential diagnosis of epidermoid cysts originated from subcutaneous tissues and extending to the tendons, epidermoid cysts are more superficial and cause tension more on the skin. Ganglion cyst, mucoid cyst, gouty tophus, glomus tumor, foreign body granuloma, tendon sheath fibroma, schwannoma, and malign tumors are considered for differential diagnosis of such lesions.
Medical treatment for epidermoid cysts is only applied for symptomatic purposes. Non-steroidal antiinflammatory agents can be used to relieve pain and antibiotics for treating secondary infection. ${ }^{[5]}$ Aspiration methods are technically not possible in most cases, unlike other soft tissue cysts (ganglia, synovial cyst, etc.) due to the content of the cyst composed of keratinized desquamous epithelium that is mostly in the form of cheesy and semi-solid. ${ }^{[5,15]} \mathrm{In}$ the literature, aspiration has only been reported for diagnostic purposes. ${ }^{[5]}$ Sclerosing agent injection used in various types of soft tissue tumors has been reported as case reports. ${ }^{[16,17]}$ Zhang et al. ${ }^{[17]}$ reported a case in which they injected pingyangmycin (an antibiotic used as a sclerosing agent) into the epidermoid cyst in a 20-year-old male patient. Although early lesion regression was reported, they surgically excised the cyst after regrowth in the third month.

In the literature, there is restricted information regarding non-invasive treatment methods in epidermoid cysts. ${ }^{[17]}$ We believe that these lesions should be treated surgically due to possible secondary infectious development, while malignant transformation has been reported rarely and spontaneous improvement have not been reported. ${ }^{[5]}$

When curettage and excision are preferred in intraosseous epidermoid cysts, marginal excision is recommended for epidermoid cysts with soft tissue localization. ${ }^{[5]}$ The important issue here is thorough clinical and radiological examination of the mass before surgery and establishing benign-malign differentiation accurately. Orthopedic oncology principles should be followed during diagnosis and treatment phases. Otherwise, a possible malign pathological result after marginal excision may cause problems both for the patient and the surgeon. Rates for malign transformation were reported as $0.011-0.045 \%$ in the literature. ${ }^{[4]}$ In such case, the treatment recommended is re-excision with clear surgical margins. Since all cases were considered to have a benign cystic formation clinically and radiologically and no excision was planned, we did not detect any malign transformation in the present study. The relapse ratio of the present study was $10 \%(\mathrm{n}=12)$ and intraoperative rupture ratio was found statistically significantly higher in such cases whereas ratio of excision with a cutaneous islet was detected as statistically significantly lower. The rupture site was considered as the site where the cyst had most contact with the skin; therefore, we applied a marginal excision by leaving a cutaneous islet like the procedure applied for malign tumors during further surgeries. The lesion is originated from the skin; thus, 
excision without leaving a cutaneous islet would be an intralesional excision rather than a marginal excision.

Nevertheless, Lucas ${ }^{[18]}$ reported a relapse ratio of $17 \%$ in their study and suggested that relapse is associated with incomplete excision. Lincoski et al. ${ }^{[6]}$ found a relapse ratio of $11 \%$ and reported that preoperative rupture of the cyst is not correlated with relapse and relapse was considered to be caused by incomplete excision rather than intraoperative cyst rupture. For this purpose, such authors recommended to perform excision of the cyst with the skin including scar tissue in patients with penetrating trauma history. In contrast to Lincoski's study, we found that the ratio of relapse was significantly higher in patients with intraoperative rupture. We think that the reason for this is; form of treatment is converted from marginal excision to intralesional excision by having intraoperative rupture, because the surrounding tissue is contaminated by the pathological cell planting via intralesional excision. ${ }^{[6]}$ As a result of the data obtained from the present study, depending on the hypothesis that the skin on the cyst with/ without trauma history is defective to be predisposed to epidermoid cyst formation and possible defects on such site may allow transmission of epidermal formations into the dermis, we recommend removal of the cysts with cutaneous islets. Despite the current literature, we observed that intraoperative rupture is a reason for relapse of the cyst in the present study and concluded that this may be reduced by excision with cutaneous islet on the cyst.

The present study has some limitations. The first is the retrospective design of our study. The method including excision of the epidermoid cyst with the skin islet should be adopted and further randomized controlled prospective studies with higher number of cases should be planned to investigate the factors affecting relapse.

In conclusion, epidermoid cysts are most common on the hands. However, they may be atypically localized with different dimensions and characteristics. Therefore, well definition of the cyst margins and characteristics and avoiding intraoperative rupture while excising the cyst together with the cutaneous islet are essential to reduce possible postoperative complications and relapse ratios.

\section{Declaration of conflicting interests}

The authors declared no conflicts of interest with respect to the authorship and/or publication of this article.

\section{Funding}

The authors received no financial support for the research and/or authorship of this article.

\section{REFERENCES}

1. Meyer I. Dermoid cysts (dermoids) of the floor of the mouth. Oral Surg Oral Med Oral Pathol 1955;8:1149-64.

2. Enzinger FM, Weiss SW. Softtissuetumors. 2nd ed. St. Louis: Mosby; 1988.

3. Kirkham N, Tumorsandcysts of theepidermis. In: Elder DE, Elenitsas R, Johnson BL, Murphy GF Jr, editors. Lever's Histopathology of the Skin. 9th ed. Philadelphia: Lippincott Williams Wilkins; 2005. p. 805-66.

4. Anton-Badiola I, San Miguel-Fraile P, Peteiro-Cancelo A, Ortiz-Rey JA. Squamous cell carcinoma arising on an epidermal inclusion cyst: a case presentation and review of the literature. Actas Dermosifiliogr. 2010;101:349-53.

5. Dutta M, Saha J, Biswas G, Chattopadhyay S, Sen I, Sinha R. Epidermoid cysts in head and neck: our experiences, with review of literature. Indian J Otolaryngol Head Neck Surg 2013;65:14-21.

6. Lincoski CJ, Bush DC, Millon SJ. Epidermoid cysts in the hand. J Hand Surg Eur Vol 2009;34:792-6.

7. McFarland GB. Soft tissue tumors. In: Green DP, editor. Operative Hand Surgery. New York: Churchill Livingstone; 1988. p. 2301-22.

8. Wien MS, Caro MR. Traumatic epithelial cysts of the skin. JAMA 1934;102:197-200.

9. Carroll RE. Epidermoid (epithelial) cyst of the hand skeleton. Am J Surg 1953;85:327-34.

10. Hamad AT, Kumar A, Anand Kumar C. Intraosseous epidermoid cyst of the finger phalanx: a case report. J Orthop Surg (Hong Kong) 2006;14:340-2.

11. Bhagwandas $\mathrm{K}$, Nicolaou $\mathrm{N}$, Roberts DL. Intraosseous epidermoid cyst mimicking psoriasis. Br J Dermatol 2001;145:366-8.

12. Atik OŞ, Bozkurt HH, Özcan E, Bahadır B, Uçar M, Öğüt B, et al. Localized pigmented villonodular synovitis in a child knee. Eklem Hastalik Cerrahisi 2017;28:46-9.

13. Hong SH, Chung HW, Choi JY. MRI findings of subcutaneous epidermal cysts: emphasis on the presence of rupture." AJR M J Roentgenal 2006;186:961-6.

14. Bohler I, Fletcher P, Ragg A, Vane A. A Ruptured Digital Epidermal Inclusion Cyst: A Sinister Presentation. Case Rep Orthop. 2016;2016:9035246.

15. Hegde PN, Prasad H L K, Kumar Y S, Sajitha K, Roy PS, Raju $\mathrm{M}$, et al. A Rare Case of an Epidermoid Cyst in the Parotid Gland - which was Diagnosed by Fine Needle Aspiration Cytology. J Clin Diagn Res 2013;7:550-2.

16. Mai HM, Zheng JW, Zhou Q, Yang XJ, Wang YA, Fan XD. Intralesional injection of pingyangmycin is a safe and effective treatment for microcystic lymphatic malformations in the tongue. Phlebology 2013;28:147-52.

17. Zhang L, Zheng J, Mai HM, Zhu L, Zhang L, Zheng JW. Efficacy of pingyangmycin injection for the treatment of cervical epidermoid cysts. Int J Clin Exp Med 2013;6:81-3.

18. Lucas GL. Epidermoid inclusion cysts of the hand. J South Orthop Assoc 1999;8:188-92.

19. Enneking WF, Spanier SS, Goodman MA. A system for the surgical staging of musculoskeletal sarcoma. Clin Orthop Relat Res 1980;153:106-20. 